\title{
PEMANFAATAN FITUR REMOTE CONTROL MELALUI MEDIA BLUETOOTH PADA TELEPON SELULER SEBAGAI ALAT BANTU PROSES PENGAJARAN
}

\author{
Indra Kusumadi Hartono \\ Jurusan Sistem Informasi, Fakultas Ilmu Komputer, Binus University \\ Jl. K.H. Syahdan No.9, Palmerah, Jakarta Barat 11480 \\ indrakh@binus.ac.id
}

\begin{abstract}
Teaching methods commonly require dynamic presentation techniques. Cellular phone technology can be utilized as a remote control via Bluetooth. Several experiments are conducted in simple ways to measure the effective distance between the device cell phone-notebook and PC-cell phone. Based on the research, it is concluded that local cell phones turned out to be acceptable as a teaching device utilized at campus.
\end{abstract}

Keywords: cellular phone, Bluetooth, remote control, teaching

\begin{abstract}
ABSTRAK
Pada umumnya metode pengajaran memerlukan teknik presentasi yang dinamis. Teknologi telepon seluler dapat dimanfaatkan sebagai remote control melalui media Bluetooth. Beberapa percobaan dilakukan dengan cara sederhana untuk mengukur Jarak efektif antara piranti ponsel-notebook dan ponsel-PC. Berdasarkan hasil penelitian, bisa disimpulkan bahwa ponsel lokal ternyata cukup memadai sebagai alat bantu proses pengajaran di kampus.
\end{abstract}

Kata kunci: telepon seluler, Bluetooth, remote control, pengajaran 


\section{PENDAHULUAN}

Proses belajar-mengajar di kampus memerlukan teknik pengajaran yang menarik. Untuk itu, interaksi antara dosen dengan mahasiswa hendaknya tidak statis karena hal tersebut akan membosankan bagi para mahasiswa. Penciptaan lingkungan pembelajaran yang positif akan memberikan suasana kelas responsive (Polla, 2008). Teaching and Educational Development Institute, University of Queensland, memberikan beberapa petunjuk dalam Presentation Skills for Teachers (2003), bahwa cara presentasi yang menarik ialah dengan memberikan ruang gerak yang dinamis.

Melalui pola belajar interaktif, mahasiswa merasa lebih dilibatkan dalam proses pembelajaran, sehingga dapat menyimpan informasi lebih banyak serta lebih merasa terpuaskan (Steinert \& Snell, 1999). Pergerakan dinamis dosen di dalam kelas sangat dianjurkan. Namun, pada prakteknya, pergerakan dalam ruang kelas masih memiliki beberapa keterbatasan. Hal tersebut adalah karena dosen kerapkali harus menekan langsung mouse atau keyboard secara fisik, guna mengganti halaman presentasi. Dengan demikian, haruslah diciptakan kondisi yang lebih nyaman, agar dosen dapat leluasa mengganti presentasi tanpa harus berinteraksi langsung dengan alat input komputer. Pemanfaatan telepon seluler (selanjutnya akan disebut sebagai ponsel) dengan fitur Remote Control dengan notebook melalui Bluetooth dapat menjadi solusi masalah tersebut.

Bluetooth adalah standar teknologi untuk pertukaran data jarak dekat (menggunakan transmisi radio gelombang rendah) pada piranti tetap dan bergerak. Beberapa ponsel dibuat dengan chipset yang telah memiliki fitur Bluetooth. Bilamana notebook (atau PC) tidak memiliki fitur Bluetooth, piranti keras berupa Bluetooth Adapter (atau Bluetooth USB Dongle) yang harganya relatif terjangkau di pasaran perlu ditambahkan.

Makalah ini akan mencoba menguraikan pemanfaatan ponsel sebagai Remote Control disertai dengan hasil eksperimen yang dilakukan secara individual dengan skala sederhana, yaitu dalam ruang kelas Kampus Anggrek dan Kampus Kijang, Binus University, Jakarta.

\section{METODE}

Beberapa eksperimen dengan skala kecil dan sederhana dilakukan pada beberapa sesi pertemuan tatap muka bulan Februari 2011. Berlokasi di Kampus Anggrek dan Kampus Kijang, Binus University Jakarta. Eksperimen menggunakan 10 jenis jarak uji untuk kemudian diambil simpilan, berapa jarak efektif antara piranti Remote Control Ponsel dengan PC dan notebook.

Percobaan menggunakan skala Likert (Box et al, 2005) dengan lima jenis ukuran: Sangat Baik, Cukup Baik, Baik, Kurang Baik dan Tidak Baik. Eksperimen menguji daya terima dan respon dari kedua alat, kemudian diambil nilai jarak rata-rata (avarage) jarak sebagai acuan jarak efektif.

Dalam percobaan yang dilakukan, digunakan ponsel merek IVIO tipe GC-2000 (Gambar 1). ponsel ini dipilih karena sudah memiliki fitur Bluetooth, mendukung GSM-CDMA/GSM, terdapat banyak dipasaran dan harga relatif terjangkau. Ponsel ini sering disebut sebagai "ponsel lokal” dengan operating system menggunakan Nucleus Real Time Operating System (RTOS).

Fitur Bluetooth Remote Control biasanya sudah tersedia dan menjadi fitur standar pada Nucleus RTOS. Pada banyak jenis "ponsel Lokal” yang memiliki spesifikasi yang hampir mirip dengan ponsel ini, umumnya sudah dibekali fitur Bluetooth Remote Control. Sedangkan notebook yang digunakan bermerek ASUS tipe A42J Series, yang juga telah memiliki fitur Bluetooth. 
Sementara itu, untuk percobaan pada PC di ruang kelas, diperlukan sebuah Bluetooth USB Dongle sebagai piranti tambahan (Gambar 10). Mengingat semua PC di Kampus Anggrek dan Kampus Kijang, tidak memiliki fitur tersebut.

Eksperimen ini tidak dilakukan dengan berbagai ponsel yang berbeda OS (seperti: Symbian, Android, Blackberry, iPhone atau lainnya) mengingat keterbatasan waktu dan biaya. Justifikasi peneliti lainnya, ialah bahwa "ponsel Lokal” dan Bluetooth USB Dongle (Gambar 2), harganya relatif lebih terjangkau. Eksperimen dilakukan untuk mencari: Jarak efektif konektifitas ponsel-notebook maupun ponsel-PC, dimana percobaan dilakukan secara terpisah. Jarak efektif merupakan jarak ideal antar-piranti tersebut, dimana dosen dapat bergerak dinamis dalam ruang kelas. Lalu pada jarak tersebut dosen dapat menggunakan ponsel untuk mengganti halaman presentasi (baik OpenOffice Impress maupun Microsoft PowerPoint) tanpa harus kembali ke meja dosen, tetapi cukup hanya dengan memanfaatkan ponsel sebagai Remote Control. Tabel 1 dan 2 berikut ini adalah uraian spesifikasi fitur ponsel dan jenis Operating System (OS) (IVIO, n.d.).

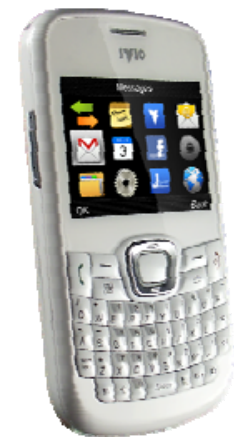

Gambar 1. Ponsel IVIO GC-2000.

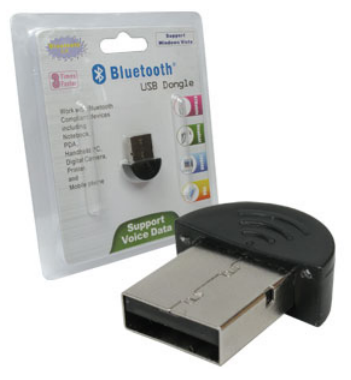

Gambar 2. Bluetooth USB Dongle sebagai piranti tambahan.

Tabel 1

Fitur Ponsel IVIO Tipe GC-2000

\begin{tabular}{cc}
\hline \multicolumn{3}{c}{ FITUR UMUM } \\
\hline \multirow{2}{*}{ Tri-Mode GSM+CDMA/GSM } \\
(Dual Band 900 Mhz dan 1800 Mhz, \\
CDMA: 800 Mhz)
\end{tabular}

Tabel 2

Jenis Operating System (OS)

\begin{tabular}{|c|c|c|}
\hline No & $\begin{array}{c}\text { Jenis } \\
\text { Piranti Keras } \\
\end{array}$ & $\begin{array}{c}\text { Jenis } \\
\text { Operating System (OS) }\end{array}$ \\
\hline 1 & Notebook & KUBUNTU 10.10 (derivatif Linux UBUNTU versi 10.10) \\
\hline 2 & Personal Computer (PC) & Microsoft Windows XP \\
\hline
\end{tabular}




\section{HASIL DAN PEMBAHASAN}

Proses percobaan konektifitas ponsel-notebook dilaksanakan pada kelas yang terpisah dengan konektifitas ponsel-PC. Hal tersebut dilakukan untuk mengukur jarak efektif yang dapat diterima dengan baik oleh kedua piranti. Rangkaian proses tersebut, adalah sebagai berikut: (a) Awal proses adalah aktifasi fitur Bluetooth pada ponsel dan notebook. Setelah itu, notebook dilakukan proses penambahan alat (Add Remote Device). Setelah menemukan ponsel sebagai alat aktif, lalu ponsel dibuat sebagai Remote Device. Proses selanjutnya adalah Pairing, dimana notebook akan mengirimkan PIN (berupa 4 digit numerik) yang harus dimasukkan ke dalam ponsel. Jika Pairing berhasil, akan disediakan opsi layanan yang hendak digunakan. Pilihan yang tersedia: Send File, Input dan None. Pilihan Input dieksekusi. Setelah itu aktifkan fitur Remote Control pada ponsel. Dengan demikian, ponsel telah siap menjadi Remote Control. Langkah terakhir adalah penyiapan aplikasi presentasi OpenOffice Impress serta berkas yang akan dipresentasikan; (b) Proses selanjutnya adalah konektifitas notebook dengan Overhead Projector (OHP) sebagai alat keluaran (output) yang akan mengirimkan keluaran terhadap proses presentasi yang sedang dilaksanakan. Gambar 3 berikut ini menjelaskan proses konektifitas antar-piranti keras.

Dalam percobaan lainnya, digunakan konektifitas ponsel-PC. Rangkaian proses konektifitas, pada prinsipnya hampir sama dengan proses (a) dan (b). Perbedaan signifikan kondisi (c) dan (d), adalah menggunakan PC berbasis operating system Windows XP. Namun, beberapa proses seperti: Add Device, Pairing dan pemilihan jenis layanan dalam OS berbasis Windows XP dan Linux KUBUNTU versi 10.10 tidak memiliki perbedaan signifikan. Gambar 4 dan 5 berikut ini menjelaskan proses konektifitas ponsel-notebook dengam menggunakan Operating System berbasis Linux KUBUNTU versi 10.10 .

Setelah ponsel dan notebook (atau PC) terhubung, dilakukan eksekusi aplikasi presentasi (baik OpenOffice Impress atau Microsoft PowerPoint). Kemudian berkas yang akan dipresentasikan dipilih. Sedangkan pada ponsel, dipilihlah fitur Remote Control. Dengan demikian, siaplah dosen untuk melakukan presentasi yang lebih dinamis, leluasa tanpa harus terus-menerus kembali ke meja dosen untuk mengganti halaman presentasi.

Notebook ataupun PC, tidak membutuhkan piranti lunak/aplikasi tambahan. Jika konektifitas ponsel dengan piranti tersebut telah terhubung, ponsel hanya menggunakan human input device (HID) profile dari beberapa fitur profile yang tersedia. Dengan demikian, ponsel akan berfungsi sebagai alat input. Sementara fungsi standar ponsel lainnya (seperti: SMS, koneksi telepon dan lainnya) tetap dapat tetap berfungsi dengan baik, meskipun fitur Remote Control sedang dimanfaatkan. Eksperimen dilakukan dengan menggunakan empat lokasi kelas yang berbeda, dua berada di Kampus Anggrek dan dua lainnya di Kampus Kijang. Komposisi eksperimen menggunakan ponsel-notebook dalam tiga sesi tatap muka, serta ponsel-PC yang juga dalam tiga sesi tatap muka. Sehingga kedua jenis konetifitas diuji-coba dengan kuantitas yang sama besar. Dari semua konektifitas tersebut, tidak ditemukan kegagalan koneksi. Semua piranti ponsel-notebook maupun ponsel-PC dapat terkoneksi dengan baik.

Proses konektifitas ponsel-notebook, seperti dalam Gambar (a), memerlukan waktu sekitar kurang dari satu menit. Sedangkan ponsel-PC, seperti dalam Gambar 2 (c) sekitar dua menit. Sedangkan jarak efektif yang diukur oleh peneliti merupakan jarak ponsel dengan meja dosen, dimana piranti tersebut berada. Hasil pengukuran jarak efektif tersebut jika ada dalam Tabel 3 berikut ini. Dalam jangkauan jarak efektif, fitur Remote Control ponsel dapat bekerja baik. Semua fungsi dalam fitur Remote Control dapat digunakan. Namun, jika jarak efektif terlampaui, ponsel akan kehilangan fitur Remote Control. Peneliti harus kembali dalam jangkauan jarak efektif agar konektifitas kedua piranti tersebut dapat kembali berfungsi normal. 


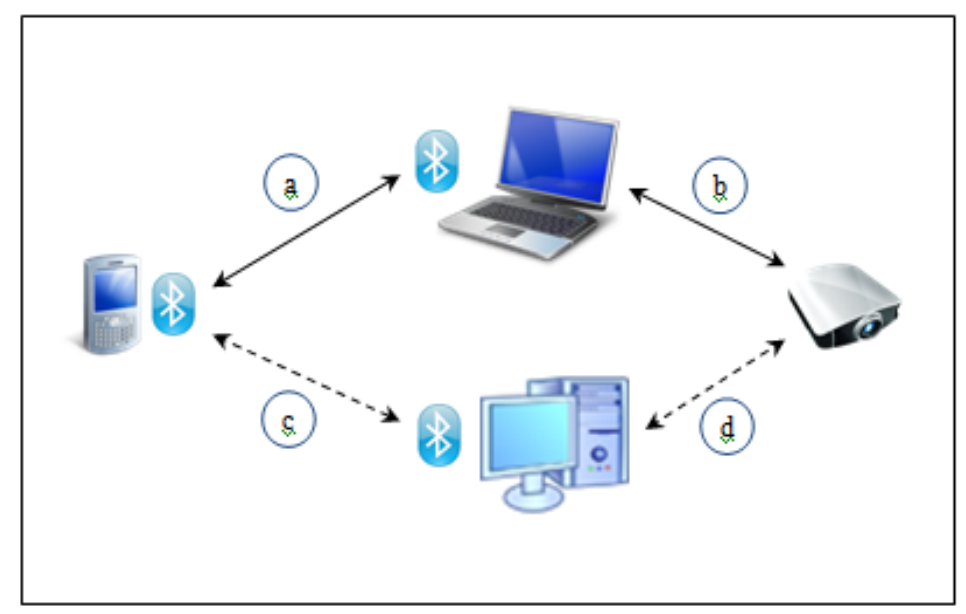

Gambar 3. Konektifitas telepon seluler sebagai Remote Control dengan notebook dan PC melalui Bluetooth yang keluarannya diteruskan ke Overhead Projector.

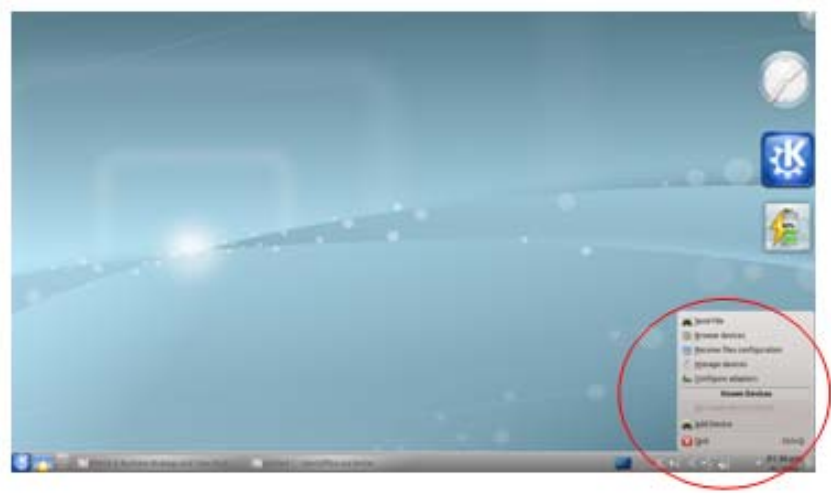

Gambar 4. Tampilan Graphical User Interface (GUI) Bluetooth dalam Linux Kubuntu 10.10.

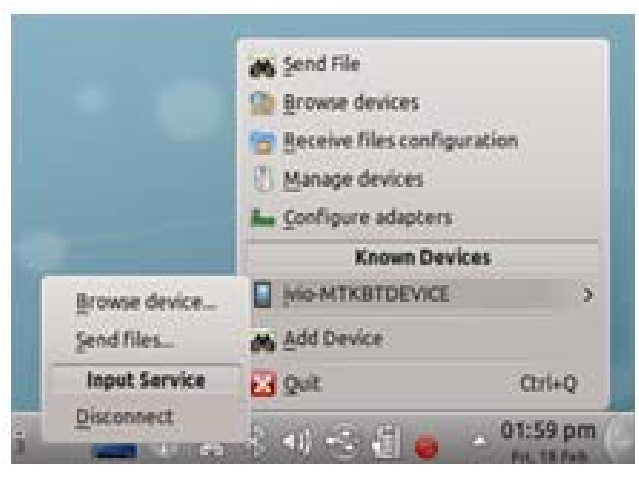

Gambar 5. Tampilan ponsel telah siap digunakan sebagai Remote Control.

Tabel 3

Perbandingan Jarak Efektif Menggunakan Kualitas Konektifitas Ponsel (Sebagai Remote Control) dengan Piranti Keras

\begin{tabular}{rrcc}
\hline No & $\begin{array}{c}\text { Jarak } \\
\text { (meter) }\end{array}$ & $\begin{array}{c}\text { PC di ruang } \\
\text { kelas }\end{array}$ & Notebook \\
\hline 1 & 0.3 & Sangat Baik & Sangat Baik \\
2 & 0.6 & Sangat Baik & Sangat Baik \\
3 & 0.9 & Cukup Baik & Sangat Baik \\
4 & 1.2 & Cukup Baik & Sangat Baik \\
5 & 1.5 & Baik & Cukup Baik \\
6 & 1.8 & Baik & Cukup Baik \\
7 & 2.1 & Kurang Baik & Baik \\
8 & 2.4 & Kurang Baik & Baik \\
9 & 2.7 & Tidak Baik & Kurang Baik \\
10 & 3 & Tidak Baik & Kurang Baik \\
\hline
\end{tabular}




\section{PENUTUP}

Meskipun kemampuan Bluetooh Class 2 secara teknis dapat menjangkau jarak 10 meter (Haartsen, 2000), namun dalam eksperimen ini, jarak tersebut tidak optimal. Peneliti berpendapat bahwa hal tersebut adalah kemungkinan besar karena piranti ponsel, tidak memiliki daya pancar dan daya terima transmisi sinyal Bluetooth yang baik. Demikian pula halnya dengan Bluetooth USB Dongle yang dipasang di PC, besar kemungkinan tidak memiliki kemampuan transmisi sinyal sebaik piranti internal notebook. Peneliti berpendapat bahwa kedua piranti ponsel serta Bluetooth USB Dongle memang dirancang untuk transmisi jarak dekat saja, yaitu sekitar dua hingga tiga meter. Eksperimen ini dilakukan menggunakan tipe "ponsel lokal". Karena keterbatasan waktu dan biaya, tidak digunakan tipe ponsel yang lebih beragam. Jika ada kesempatan lainnya, penelitian lanjutan dengan durasi waktu yang lebih panjang dan biaya yang lebih besar akan dapat memberikan hasil lebih variatif dan akurat. Namun demikian, tipe "ponsel lokal" sudah cukup memadai untuk dimanfaatkan sebagai Remote Control dan cukup banyak membantu serta mempermudah proses pengajaran, dimana pergerakan dinamis dosen pada saat presentasi sangat diperlukan.

\section{DAFTAR PUSTAKA}

Box, G. E., Hunter,W.G., Hunter, J.S., Hunter,W.G. (2005). Statistics for Experimenters: Design, Innovation, and Discovery (2nd ed.). New Jersey: John Wiley \& Sons.

Gerardus Polla, et. al. (2008). Teaching Excellence: Reflection on Teaching \& Learning. Jakarta: Widia Centre of Excellence for Teaching and Learning (WiTel), Binus University.

Haartsen, J. C. (2000). The Bluetooth Radio System. IEEE Personal Communications, 7 (01).

IVIO. (n.d.) Spesifikasi Ponsel IVIO GC-2000. Diakses 18 Februari 2011 dari http://www.ivio.com/mobile.php?ponsel=GC2000\&view=specification

University of Queensland Australia. (2003). Teaching and Educational Development Institute. Presentation Skills for Teachers. 